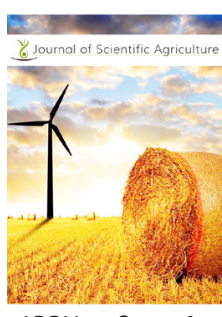

ISSN: $2184^{-0} 0261$

\title{
An anatomical screening of white jute accessions for fibre content
}

\author{
Arju Miah*, A. K. M. Shahadat Hossain', Nihar Ranjan Saha², \\ Md. Younus Ali³, Md. Jahangir Alam', Md. Hasanuzzaman²
}

\begin{abstract}
${ }^{1}$ Genetic Resources and seed Division, Bangladesh Jute Research Institute, Manik Mia Avenue, Dhaka - 1207, Bangladesh, ${ }^{2}$ Department of Biotechnology, Bangladesh Agricultural University, Mymensingh-2202, ${ }^{3}$ Fibre Quality Improvement Division, Bangladesh Jute Research Institute, Manik Mia Avenue, Dhaka - 1207, Bangladesh
\end{abstract}

\begin{abstract}
The present study was conducted to evaluate the performance of 24 advanced lines of white jute and four check varieties ( CVL-1, CC-45, BJRI Deshi Pat-7 \& BJRI Deshi Pat-8) for screening out high yielding and better quality fibre through an anatomical approach at JAES, Manikganj. The experiment was conducted in randomly complete block design (RCBD) with three replications. The cultivars revealed significant differences among them for all the characters with range of variability. The highest bark thickness $(2.32 \mathrm{~mm})$ was noticed by the accession C-5036 which performed significantly better than the two checks and lowest was recorded by C-5126 $(1.07 \mathrm{~mm})$. The variety BJRI Deshi Pat-8 observed significantly the highest number of pyramid (54.13) whereas the lowest was recorded by the varieties BJRI Deshi Pat-7 (28.23). The accession C-5117 showed significantly the highest number of layer (10.29) whereas the variety, BJRI Deshi Pat-7 showed significantly lowest number of layer (6.32). The accession C-2305(92.37) and C-1222l (91.19) significantly showed top two number of fibre bundle, however, the lowest number of fibre bundle was recorded by BJC-5105(42.79). The largest area of pyramid was observed by the accession C-5036 (46.85 sq. mm) whereas the lowest was showed by BJC-5105 (14.50 sq. mm). The differences between Phenotypic Coefficient of Variation (PCV) and Genotypic Coefficient of Variation (GCV) were little for all the characters indicating these characters were less influenced by the environment. Heritability and genetic advance (GA) were high for number of pyramid, number of fibre, bundle and Area of pyramid (sq.mm). Three accessions(C-12221, C-2305, C-5036) are showed the best performance than other accession on our screening program. These accessions are included in cluster $V$ among the five clusters which exhibit the highest performance in all parameter except number of pyramid and may be used in further hybridization of jute.
\end{abstract}

*Corresponding Author: Arju Miah,

E-mail: arjumia146@gmail. com

KEYWORDS: Anatomical Screening, D2 statistics, variability, correlation Fiber content, White jute (Corchorus capsularis L.)

Received: July 08, 2020

Accepted: August 01, 2020

Published: August 08, 2020 genus Corchorus namely Corchorus capsularis L. and Corchorus olitorius L. The fibres are grouped into bundles and are arranged in trapezoid wedges (pyramid) and alternate with medullary rays of soft tissue. The fibre bearing potentiality of jute plants largely depends on the number of fibre trapezoids, size of fibre bundles and their compactness [4]. Several workers have studied the compactness of fibre bundles of different species of Corchorus [5,6,7] and some of them reported that the area of cell/section has the highest significant correlation with fibre yield/plant [8].

Bast fibres are part of vegetative biomass as they are formed in the secondary phloem region in jute stem. Yield of bast fibres which are produced within the bark of the stem of bast fibre crop can't be assessed unless the plants are retted and fibres extracted. This procedure of yield assessment is long waiting and costly. So, we can easily isolate higher fibre bearing 
potentiality genotypes through anatomical studies i.e. fibre compactness per unit area of plant bast. The quality of jute fibre depends mainly on the length and length-breadth ratio of ultimate fibres. The ultimate fibre of jute varies from 500 to $6500 \mu \mathrm{m}$ in length and 10 to $30 \mu \mathrm{m}$ in diameter [9]. The length-breadth ratio of ultimate fibres for fine yarn production should be about 1000-2000 [10] but in jute this ratio is an average only about 120 [9]. Many workers studied the ultimate fibre cells of different varieties of Corchorus olitorius L $[6,11]$. The present study was undertaken for selection of cultivars of white jute having high fibre bearing potentiality based on anatomical screening approach.

\section{METHODS AND MATERIALS}

23 advanced lines of white jute and four released varieties namely, CVL-1, CC-45, BJRI Deshi Pat-7 \& BJRI Deshi Pat-8 were used as experimental materials. The cultivars were grown at the JAES, Manikganj in a randomized complete block design with three replications. A plot for each genotype was represented by 3 rows of $3.6 \mathrm{~m}$ length with a spacing of $30 \mathrm{~cm}$ $x 5 \mathrm{~cm}$. Standard agronomic practices were followed. At the age of 110 days of maturity, five plants were selected randomly from each replication for harvest. The middle portion of stem $(5 \mathrm{~cm}$ stem piece) were collected and preserved in Formalin acetic acid alcohol solution ( $10 \mathrm{ml}$ of formalin, $5 \mathrm{ml} 85 \%$ glacial acetic acid and $85 \mathrm{ml}$ of $70 \%$ alcohol) for anatomical study. The preserved sample were taken out and washed. About $20-25 \mu \mathrm{m}$ thick transverse sections (TS) was done with the help of a microtome machine for preparing slide. The slides were studied under compound microscope (4X10 magnifications) and data were recorded for bark thickness, number and area of phloem wedges, number of fibre bundle layers and number of fibre bundles per section. Plant weight, base diameter and dry fibre weight of the materials were also recorded.

Meceration of fibre cell: The fibre was extracted following the method described by Aziz et al. 1964 with little modification. The anatomical data were recorded from 5-10 randomly selected plants of each genotype from each replication at the time of harvest (110 days of crop age). Data were recorded on date of sowing, germination, $1^{\text {st }}$ and average flowering. Bark diameter, bark thickness, number of trapezoids/section were calculated for three plants of each accession under microscope. Area of trapezoid/section $(\mu \mathrm{m})$ : Area of trapezoid was measured by the following formula: (Area of trapezoid $=1 / 2($ Upper length + Lower length) X perpendicular length of trapezoid X conversion factor [Conversion factor $=39.4$ in 4 X 10 magnification], number of layers/ trapezoid, number of bundles/trapezoid were calculated under microscope from randomly selected trapezoid. Length, breadth and length: breadth ratio to be measured for 10 randomly selected the fibre cells by using oculometer under the microscope

Analysis of variance and covariance were done according to [12] Coefficient of variation (PCV and GCV) and heritability (H2b) were calculated by the formulae suggested by [13 and 14], respectively. Genetic advance (GA) was derived by the formula given by [15] A cluster diagram was drawn according to [16] that gave a brief idea of the pattern of diversity among the genotypes included in a cluster.

\section{RESULT AND DISCUSSION}

The analysis of variance of different advanced lines of white jute for anatomical characteristics is shown in Table 1. Analysis of variance shows that the difference among genotypes for all the traits under study viz., Bark thickness (mm), Number of pyramid, Number of layer, Number of fibre Bundle and Area of pyramid (sq.mm) were highly significant.

The mean performance of 24 advanced line and four check varieties for five anatomical characteristics are shown in Table 2.

Among the accession and varieties, significantly the highest bark thickness $(2.32 \mathrm{~mm})$ was found from the accession C-5036 which was followed by accession C-12221 (2.23 mm) and lowest was recorded by C-5126 (1.07 mm). Bark thickness is an important character for fibre yield of Jute accession or varieties in case of the higher bark thickness produce the better thickness of fibre which will ensure the higher production of fibre. In our findings, the great variation was observed by both the accession and varieties where the accession showed better performance than the check varieties. These results are supported by the findings of Pervin and Haque (2012), Haque et al. (1977).The varieties BJRI Deshi Pat-8 showed significantly the maximum number of the pyramid (54.13) followed by C-1831x A-38 (42.78). On the contrary, significantly the lowest number of the pyramid was noticed by the varieties BJRI Deshi Pat-7 (28.23) which was closely followed by C-2236 (29.70). It was found that the accession C-5117observed significantly the maximum number of layer (10.2) which was followed by accession C-12221 (9.76). On the other hand, the variety, BJRI Deshi Pat-7 showed significantly the lowest number of layer (6.32) followed by the variety CC45 (6.96). The two anatomical characters including the number of the pyramid and the number of layers was significant with the mean performance of fibre yield. Though one of the varieties recorded significantly the highest number of the pyramid, the highest number of the layer was recorded by an accession significantly. So, both the number of pyramid and number of the layer can be used as compatible criteria for screening of jute through the anatomical approach. The Results of $[17,18,19]$ were also in agreement with our findings. The highest number of the fibre bundle (92.37) was observed by the accession C-2305 followed by accession C-12221 (91.19) whereas the lowest was recorded by BJC-5105 (42.79). The largest area of the pyramid was recorded by the accession C-5036 (46.85 sq. mm) followed by the accession C-5044 (41.17 sq. mm) whereas the lowest was showed by BJC-5105 (14.50 sq. mm). These findings are following $[17,8,20,6]$.

The considered traits studied in the present investigation showed high heritability ranging from $92.34 \%$ to $97.95 \%$. Among the traits studied the highest heritability was recorded by Area of pyramid (97.95\%) followed by the number of fibre bundle 
Table 1: Analysis of variance of different advanced lines of white jute for anatomical characteristics

\begin{tabular}{lcccccc}
\hline $\begin{array}{l}\text { Source of } \\
\text { variation }\end{array}$ & $\mathrm{df}$ & $\begin{array}{c}\text { Bark thickness } \\
(\mathrm{mm})\end{array}$ & $\begin{array}{c}\text { No. of } \\
\text { pyramid }\end{array}$ & $\begin{array}{c}\text { No. of } \\
\text { layer }\end{array}$ & $\begin{array}{c}\text { No. of fibre } \\
\text { Bundle }\end{array}$ & $\begin{array}{c}\text { Area of pyramid } \\
(\text { sq.mm})\end{array}$ \\
\hline $\begin{array}{l}\text { Replication } \\
\text { Accessions }\end{array}$ & 2 & 0.003 & 0.799 & 0.071 & 3.305 & 0.664 \\
Error & 27 & $0.435^{* *}$ & $81.851^{* *}$ & $2.863^{* *}$ & $396.063^{* *}$ & $288.264^{* *}$ \\
\hline
\end{tabular}

** $=$ Significant at $1 \%$ level of probability

Table 2: Mean performance of anatomical characteristics for different advanced lines of white jute

\begin{tabular}{|c|c|c|c|c|c|}
\hline Accessions & Bark thickness (mm) & No. of pyramid & No. of layer & No. of fibre Bundle & Area of pyramid (sq.mm) \\
\hline C-2281 & $1.31^{\mathrm{f}}$ & $33.37^{\mathrm{k} \_\mathrm{m}}$ & $7.42^{g_{-}} \mathrm{i}$ & $69.63^{\mathrm{fg}}$ & $16.42^{m_{-}}{ }^{0}$ \\
\hline C-3540-41 & $1.23 \mathrm{f}_{-}^{\mathrm{i}}$ & $42.32^{\mathrm{bc}}$ & $7.78^{\mathrm{fg}}$ & $67.39^{\mathrm{gh}}$ & $20.34^{k}$ \\
\hline C-2234 & $1.12^{\mathrm{h}-\mathrm{j}}$ & $34.89^{i}-1$ & $7.43^{9} \mathrm{i}^{\mathrm{i}}$ & $66.62^{\mathrm{gh}}$ & $20.48^{k}$ \\
\hline BJC-5002 & $1.32^{f}$ & $33.30^{k}-^{m}$ & $8.55^{\text {de }}$ & $65.38^{\mathrm{h}}$ & $20.63^{k}$ \\
\hline C-2236 & $1.11^{\mathrm{ij}}$ & $29.70^{\circ}$ & $7.42^{\mathrm{g}-\mathrm{i}}$ & $61.51^{i}$ & $16.67^{\mathrm{m}-0}$ \\
\hline BJC-5050 & $1.15^{\mathrm{g} \_\mathrm{j}}$ & $30.58^{\text {no }}$ & $7.56^{\mathrm{gh}}$ & $65.82^{\text {gh }}$ & $19.51^{\mathrm{kl}}$ \\
\hline BJC-5105 & $1.26^{\mathrm{fg}}$ & $30.42^{\text {no }}$ & $7.43^{9} \mathrm{i}^{\mathrm{i}}$ & $42.79^{\prime}$ & $14.50^{\circ}$ \\
\hline C-1831x A-38 & $1.25^{\mathrm{fg}}$ & $42.78^{b}$ & $7.67^{\mathrm{gh}}$ & $74.12^{\mathrm{de}}$ & $14.72 \mathrm{n}^{\circ}$ \\
\hline BJC-5003 & $1.32^{f}$ & $32.23^{\mathrm{mn}}$ & $7.23^{\text {hi }}$ & $53.33^{k}$ & $23.49^{j}$ \\
\hline C-6786 & $1.96^{\mathrm{b}}$ & $39.33^{\text {de }}$ & $9.27^{b c}$ & $71.72^{\text {ef }}$ & $31.52^{\mathrm{h}}$ \\
\hline C-6766 & $1.78^{c d}$ & $37.45^{\mathrm{e}-\mathrm{i}}$ & $9.49^{b}$ & $84.78^{c}$ & $34.57^{\mathrm{fg}}$ \\
\hline C-12221 & $2.23^{\mathrm{a}}$ & $37.56^{\mathrm{e}-\mathrm{h}}$ & $9.76^{\mathrm{b}}$ & $91.19^{\mathrm{a}}$ & $41.32^{b}$ \\
\hline C-5126 & $1.07^{\mathrm{j}}$ & $36.54^{f-j}$ & $8.68^{\text {de }}$ & $74.23^{\mathrm{de}}$ & $31.39^{h}$ \\
\hline C-5044 & $1.69^{\mathrm{de}}$ & $35.87^{9}{ }^{\mathrm{k}} \mathrm{k}$ & $9.28^{b c}$ & $74.32^{\mathrm{de}}$ & $41.17^{\mathrm{b}}$ \\
\hline C-2305 & $1.97^{\mathrm{b}}$ & $35.28^{h-1}$ & $9.39^{b c}$ & $92.37^{\mathrm{a}}$ & $37.28^{\text {de }}$ \\
\hline C-5136 & $1.87^{b c}$ & $38.22^{d-9}$ & $7.62^{\mathrm{gh}}$ & $77.35^{d}$ & $34.43^{\mathrm{fg}}$ \\
\hline C-5127 & $1.78^{\text {cd }}$ & $40.32^{\text {cd }}$ & $8.95^{c d}$ & $77.31^{d}$ & $36.57^{d_{-} f}$ \\
\hline C-5133 & $1.79^{\text {cd }}$ & $38.78^{d_{-}}{ }^{f}$ & $8.23^{\text {ef }}$ & $73.67^{\text {de }}$ & $33.50^{\text {gh }}$ \\
\hline C-5036 & $2.32^{\mathrm{a}}$ & $36.52^{f}{ }^{j}$ & $8.63^{\text {de }}$ & $89.24^{\mathrm{ab}}$ & $46.85^{a}$ \\
\hline C-5149 & $1.87^{\mathrm{bc}}$ & $37.24^{\mathrm{e}-\mathrm{i}}$ & $9.49^{b}$ & $75.25^{\text {de }}$ & $39.73^{b c}$ \\
\hline C-5117 & $1.78^{\text {cd }}$ & $35.53^{\mathrm{h}}-1$ & $10.2^{\mathrm{a}}$ & $86.12^{b c}$ & $35.62^{\mathrm{e}-9}$ \\
\hline C-2262 & $1.97^{\mathrm{b}}$ & $35.36^{h-1}$ & $8.48^{\mathrm{de}}$ & $77.41^{d}$ & $38.53^{\text {cd }}$ \\
\hline C-5030 & $1.99^{\mathrm{b}}$ & $34.34^{\mathrm{j}-\mathrm{m}}$ & $8.77^{\mathrm{d}}$ & $73.31^{\mathrm{e}}$ & $35.41^{e_{-} 9}$ \\
\hline C-5018 & $1.95^{\mathrm{b}}$ & $33.21^{1 \mathrm{~m}}$ & $8.53^{\text {de }}$ & $77.56^{d}$ & $28.37^{i}$ \\
\hline BJRI Deshi Pat-7 & $1.08^{\mathrm{j}}$ & $28.23^{\circ}$ & $6.32^{j}$ & $66.37^{\text {gh }}$ & $17.12^{1}-^{n}$ \\
\hline BJRI Deshi Pat-8 & $1.64^{\mathrm{e}}$ & $54.13^{\mathrm{a}}$ & $7.48^{\text {ghi }}$ & $56.80^{\mathrm{j}}$ & $25.79^{j}$ \\
\hline CC- 45 & $1.24^{\mathrm{f}-\mathrm{h}}$ & $30.32^{\text {no }}$ & $6.96^{i}$ & $59.78^{i j}$ & $16.69^{m}{ }_{-}^{0}$ \\
\hline CVL-1 & $1.35^{f}$ & $42.42^{b c}$ & $7.63^{\mathrm{gh}}$ & $61.23^{i}$ & $18.21^{\mathrm{k}-\mathrm{m}}$ \\
\hline LSD $_{0.05}$ & 0.116 & 2.22 & 0.454 & 3.46 & 2.31 \\
\hline Level of sign & $* *$ & $* *$ & ** & $* *$ & $* *$ \\
\hline CV $(\%)$ & 4.59 & 3.73 & 3.35 & 2.95 & 5.00 \\
\hline
\end{tabular}

** $=$ Significant at $1 \%$ level of probability, ${ }^{*}=$ Significant at $5 \%$ level of probability

(96.69\%) and lowest heritability values was recorded by no of layer $(92.34 \%)$ (Table 3).

In the present study, the mean of Bark thickness ( $1.59 \mathrm{~mm})$, Number of pyramid (6.30), Number of layer (8.28), Number of fibre (71.670), Bundle and Area of pyramid (28.64 sq.mm) was calculated. Genetic advance was the highest for the number of the Number of fibre (23.14) followed by Area of pyramid (19.92 and the lowest for Bark thickness $(0.77 \mathrm{~mm})$ among the yield contributing traits (Table 3). The genetic advance as percentage of mean was the highest for Area of pyramid (70.51 sq. mm) followed by Bark thickness $(48.35 \mathrm{~mm})$ and the lowest for the number of pyramid (23.03) (Table 3). [15] Suggested that heritability and genetic advance should always be considered jointly during selection of a suitable line or progeny. The GCV and PCV were found to differ significantly for all the fibre yield components and biotic stress factors, which indicated a major role played by the environment in the expression of these characters. This is in agreement with the findings of [22].
Relationships among different anatomical characteristics were studied through analysis of correlation among them. The correlation co-efficient among different anatomical traits of 40 white jute genotypes are presented in Table 4.

Significantly genotypic correlation was recorded for bark thickness with number of layer, number of fibre bundle and area of pyramid. Besides, Number of layer was significantly correlated with both number of fibre bundle and area of pyramid. Number of fibre bundle showed correlation significantly only with area of pyramid. On the other hand, Number of pyramid is only the parameter which is non significant with all anatomical characteristics and bark thickness was non-significant with number of pyramid. These findings are in accordance with $[23,8,20,21]$.

Depending upon the range of diversity, 28 genotypes were grouped into five clusters (Table 5 Figure 1). The distribution pattern revealed maximum number of genotypes (18 genotypes) 


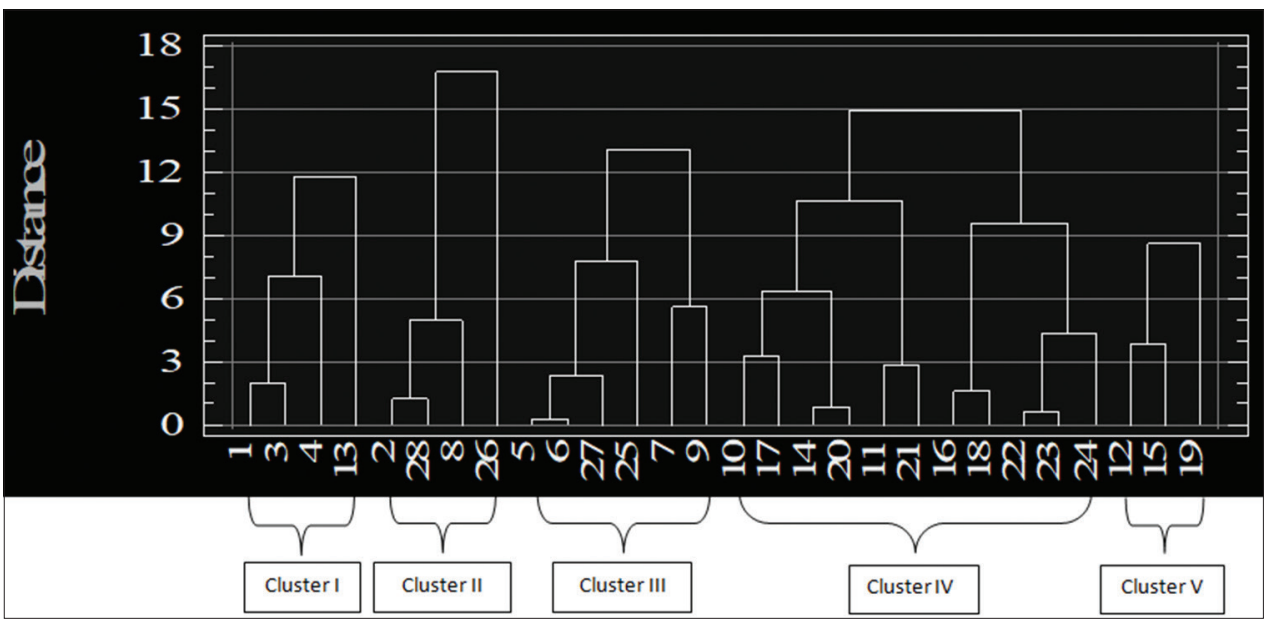

Figure 1: Dendrogram based on summarized data on differentiation among 28 accessions according to Ward's method

Table 3: Variability, heritability (h2b), genetic advance (GA) and GA in percent of mean for five yield and its related characters of 28 genotypes of white Jute

\begin{tabular}{|c|c|c|c|c|c|c|c|c|c|}
\hline SL. No. & Characters & Mean & Genotypic variance $\left(\mathrm{d}^{2} \mathrm{~g}\right)$ & Phenotypic variance $\left(d^{2} p\right)$ & GCV (\%) & $\mathrm{PCV}(\%)$ & Heritability $\left(h^{2} b\right)$ & GA & $\mathrm{GA}(\%)$ \\
\hline 1 & Bark thickness (mm) & 1.59 & 0.143 & 0.148 & 23.88 & 24.29 & 96.63 & 0.77 & 48.35 \\
\hline 2 & No. of pyramid & 36.30 & 26.672 & 28.508 & 14.23 & 14.71 & 93.56 & 10.29 & 28.35 \\
\hline 3 & No. of layer & 8.28 & 0.929 & 1.006 & 11.64 & 12.12 & 92.34 & 1.91 & 23.05 \\
\hline 4 & No. of fibre Bundle & 71.67 & 130.53 & 135.00 & 15.94 & 16.21 & 96.69 & 23.14 & 32.29 \\
\hline 5 & Area of pyramid (sq.mm) & 28.24 & 95.42 & 97.42 & 34.59 & 34.95 & 97.95 & 19.92 & 70.51 \\
\hline
\end{tabular}

Table 4: Genotypic Correlation coefficients among five characters in 28 acessions of white jute

\begin{tabular}{llccc}
\hline Characters & $\begin{array}{c}\text { No. of } \\
\text { pyramid }\end{array}$ & $\begin{array}{c}\text { No. of } \\
\text { layer }\end{array}$ & $\begin{array}{c}\text { No. of fibre } \\
\text { Bundle }\end{array}$ & $\begin{array}{c}\text { Area of pyramid } \\
\text { (sq.mm) }\end{array}$ \\
\hline Bark thickness $(\mathrm{mm})$ & $0.255^{\mathrm{NS}}$ & $0.692^{* *}$ & $0.697^{* *}$ & $0.863^{* *}$ \\
No. of pyramid & & $0.176^{\mathrm{NS}}$ & $0.109^{\mathrm{NS}}$ & $0.199^{\mathrm{NS}}$ \\
No. of layer & & & $0.728^{* *}$ & $0.781^{* *}$ \\
No. of fibre Bundle & & & & $0.759^{* *}$ \\
\hline
\end{tabular}

** indicate significant at $1 \%$ level of probability, respectability

Table 5: Number, percent and name of genotypes in different cluster

\begin{tabular}{lccc}
$\begin{array}{c}\text { Cluster } \\
\text { number }\end{array}$ & $\begin{array}{c}\text { Number of } \\
\text { varieties }\end{array}$ & $\begin{array}{c}\text { Percent } \\
(\%)\end{array}$ & Name of Accessions \\
\hline I & 4 & 14.29 & Ac 01, Ac 03, Ac 04 and Ac 13 \\
II & 4 & 14.29 & Ac 02, Ac 08, Ac 26 and Ac 28 \\
III & 6 & 21.43 & Ac 05, Ac 06, Ac 07, Ac 09, Ac 25 and \\
& & & Ac 27 \\
IV & 11 & 39.29 & $\begin{array}{c}\text { Ac 10, Ac 11, Ac 14, Ac 16, Ac 16, Ac } \\
\text { 18, Ac 20, Ac 21, Ac 22, Ac 23 and Ac } \\
\end{array}$ \\
& & & 24 \\
V & 3 & 10.71 & C-12221, C-2305, C-5036 \\
\hline
\end{tabular}

Table 6: Cluster mean for five yield and yield characters of white jute

\begin{tabular}{lccccc}
\hline & I & II & III & IV & V \\
\hline B*ark thickness (mm) & 1.21 & 1.37 & 1.19 & 1.86 & 2.17 \\
No. of pyramid & 34.56 & 45.41 & 30.25 & 36.88 & 36.45 \\
No. of layer & 8.02 & 7.64 & 7.16 & 8.95 & 9.26 \\
No. of fibre Bundle & 68.97 & 64.89 & 58.28 & 77.16 & 90.93 \\
Area of pyramid *(sq.mm) & 22.23 & 19.77 & 18.00 & 35.40 & 41.82 \\
\hline
\end{tabular}

were in cluster IV covering $39.29 \%$ of the total studied genotypes while cluster $\mathrm{V}$ included minimum number of genotypes ( 3 genotypes each). Cluster I and II included 6 genotypes each (Table 5) A similar of clustering of tossa jute germplasm was observed by $[24,25]$ in tossa jute genotypes.

Mean performance of different clusters for different morphological traits studied are shown in Table 6. The results reflected that the thickest bark were grouped into cluster $\mathrm{V}$ (45.41) followed by cluster IV (1.86) whereas cluster III included the thinnest bark containing (1.19) genotypes.

In case of number of pyramid, cluster II showed the highest value (45.41) and cluster I showed the lowest value (34.56). In case of number of layer, cluster $\mathrm{V}$ showed the highest value (9.26) and cluster III showed the lowest value (7.16). In case of number of fibre Bundle, cluster $\mathrm{V}$ showed the highest value (90.93) followed by cluster $\mathrm{V}$ and cluster IV showed the lowest value (77.16). A similar of clustering was observed by $[25,26]$ in tossa jute genotypes.

\section{CONFLICT OF INTERESTS}

The authors have not declared any conflict of interests.

\section{ACKNOWLEDGEMENT}

We are grateful to the genetic resources and seed division, Bangladesh jute research institute, Manik Mia Avenue, Dhaka 1207, Bangladesh for the necessary facilities and encouragement. 


\section{REFERENCE}

1. Islam MM, Ali MS. Agronomic research advances in jute crops of Bangladesh. AASCIT Journal of Biology. 2017;3:34-46.

2. Sinha MK, Sengupta D, Sen HS, Ghosh T. Jute and jute-like fibres: current situation. Scientific Culture. 2004;70: 32-37.

3. BBS (Bangladesh Bureau of Statistics). Statistics Pocket Book of Bangladesh Bangladesh Bureau of Statistics Division, Govt. of the People's Republic of Bangladesh. 2012:91-92.

4. Kundu BC, Basak KC, Sarcar PB. In: Jute in India. ICJC, Calcutta. 1959:18

5. Haque KS, Hussain M, Ahmed QA. Anatomical study on the fibre content of some strains of jute. Bangladesh Journal Jute and Fiber Research. 1977;2:37-43.

6. Islam AS, Haque M, Haque MS. Fibre-bearing potentiality of two jute hybrids. Indian Journal of Genetics and Plant Breeding. 1980;40:578-80.

7. Islam MS, Mian MAK, Ahmed S, Hossain T, and Hossain MA.. Variability in anatomical characters in relation to fibre content and quality in tossa jute (Corchorus olitorius L.).Bangladesh Journal of Plant Breeding and Genetics 2002;15:23-28.

8. Shaikh MAQ, Ahmed ZU, Khan Al, Majid MA. An anatomical screening approach to selection of high yielding mutants of jute. Journal of Environment And Experimental Botany 1980;20:287-296.

9. Kundu BC. Jute, worlds most important bast fibre crop. Economic Botany. 1956;10:203-240.

10. Turner AJ. Structure of long vegetable fibres. Journal of the Textile Institute. 1949;41: 972-984.

11. Jana M, Basak SL, Jana MK. Genetic analysis of ultimate fibre length in cultivated jute. Bangladesh Journal of Botany. 1980;9:16-21.

12. Al-Jibouri HA, Robinson HF. Genotypic and environment variances and covariance's in an upland cotton cross of interspecific origin. Agronomy Journal. 1958;50: 633-636.

13. Burton GW. Quantitative inheritance in grasses. Proceedings of the Sixth International Grassland Congress. 1952;1: 277-283.

14. Hanson CH, Robinson HF, Comstock RE. Biometrical studies of yield in segregating populations Korean lespedza. Agronomy Journal. 1956; $48:$ :268-272.

15. Johnson HW, Robinson HF, Comstock RE. Estimates of genetic and environmental variability in soybean. Agronomy Journal. 1955;47: 314-318.
16. Singh RK, Chaudhary BD. Biometrical methods of quantitative genetic analysis. Haryana Jourbnal of Horticultural Science. 1985;12: 151-156.

17. Pervin N, Haque GKNM. variability in anatomical characters in relation to fibre content and quality in white jute (Corchorus capsularis I.) IRJALS2012;1;1;4,

18. Mandal A, Datta KA. Stability analysis of a high fibre yield and low lignin content "Thick Stem" mutant in tossa jute (Corchorus olitorius L.). BioMed Research International. 2014:9.

19. Kumar V, Singh PK, Dudhane AS, De DK, Satya P. Anatomical and morphological characteristics of nine jute genotypes. Journal of Crop and Weed. 2014;10:334-9.

20. Ali MA. Correlation and regression studies between fibre yield and some anatomical characters in white jute (Corchorus capsularis L.). Bangladesh Journal of Jute and Fiber Research. 1984;9:25-30.

21. Ahmed SS, Khatun R. Anatomical screening for selection of high yielding tossa jute (C. olitorius L.). Bangladesh Journal of Plant Breeding and Genetics. 1997;10: 9-12.

22. Sawarkar A, Yumnam S, Patil SG, Mukherjee S. Correlation and path coefficient analysis of yield and its attributing traits in tossa jute (Corchorus olitorius L.). The Bioscan. 2014;9: 883-87.

23. Satyanarayana NH, Mukherjee S, Bhanu Priya, Roy S. Genetic variability and inter-relationship between fibre yield and its components in Roselle (Hibiscus sabdariffa L.) in Terai Zone of West Bengal. Vegetos. 2015;28: 135-40.

24. Roy SK, Chakraborty M, Hijam L, Mondal HA, Surje DT, Roy A Mondal A, Pal A, Kundu A, Das S Sarker P, Kheoar S, Chakraborty G, Mitra S. Studies on genetic variability and screening for fibre yield components and biotic stress factors in tossa jute (Corchorus olitorius L.) germplasm under Terai region of West Bengal Electronic Journal of Plant Breeding. 2018;9:409-423.

25. Roy SK, Karmakar PG, Bhaduri SK, Das B, Kale VA, Haque, S. Genetic diversity, variability and correlation study in tossa jute (Corchorus olitorius L.). Indian Journal of Natural Fibres, 2015;1: 225-32.

26. Roy SK, Chakraborty M, Hijam L, Mondal HA, Surje DT, Roy A, Mondal A, Pal A, Kundu A, Das S Sarker P, Kheoar S, Chakraborty G, Mitra S. Studies on genetic variability and screening for fibre yield components and biotic stress factors in tossa jute (Corchorus olitorius L.) germplasm under Terai region of West Bengal. Electronic Journal of Plant Breeding. 2018;9: 409-423. 